UDC 539.3

\title{
THE GYROSCOPIC FORCES INFLUENCE ON THE OSCILLATIONS OF THE ROTATING SHAFTS
}

\author{
P.P. Lizunov, \\ Doctor of Technical Science, Professor \\ V.O. Nedin, \\ Assistant of Professor \\ Kyiv National University of Construction and Architecture, \\ 31, Povitroflotskiy avenue, Kyiv, Ukraine
}

DOI: $10.32347 / 2410-2547.2020 .105 .223-231$

The results of numerical investigation of shafts transverse oscillations with account of gyroscopic inertia forces are presented. It is shown what the action and how the gyroscopic forces influence on the transverse oscillations of the shafts during rotation. The study has been done with computer program with a graphical interface that is developed by authors. The process of numerical solution of the differential equations of oscillations of rotating rods using the method of numerical differentiation of rod's bend forms by polynomial spline-functions and the Houbolt time integration method is described. A general block diagram of the algorithm is shown. This algorithm describes the process of repeated (cyclical) solving the system of differential equations of oscillations for every point of mechanical system in order to find the new coordinates of positions of these points in each next point of time $t+\Delta t$. The computer program in which the shown algorithm is realized allows to monitor for the behavior of moving computer model, which demonstrates the process of oscillatory motion in rotation. Moreover, the program draws the graphics of oscillations and changes of angular speeds and accelerations in different coordinate systems. Defines the dynamic stability fields and draw the diagrams of found fields. Using this program, the dynamics of a range of objects which are modeled by long elastic rods have been studied. For some objects is shown that on special rotational speeds of shafts with different lengths, in the rotating with shaft coordinate system, the trajectories of center of the section have an ordered character in the form of $n$-pointed star in time interval from excitation to the start of established circular oscillation with amplitude that harmoniously changes in time. It is noted that such trajectories are fact of the action of gyroscopic inertia forces that arise in rotation. forces.

Keywords: shafts, transverse oscillations, numerical differentiation, bend forms, gyroscopic

Introduction. The tasks of dynamics of elastic shafts' systems that rotate in fields of inertia forces have actuality while structural elements of machines and devices are designed. The rotating shafts are responsible elements in the constructions of engines, turbines, wind and hydropower plants, other machines. For these objects, in many cases, the cause of oscillations is the periodic changes of the gyroscopic inertia forces of system per time.

When the shaft rotates and begins to bend under the action of external loads, the gyroscopic forces start to transmit energy in direction that is perpendicular to the plane of bending. After it the shaft begins to oscillate in two mutually perpendicular planes of the coordinate system that rotates with it.

The behavior of rotating elastic systems that consist of shafts, rods and rotors is described by complex differential equations systems with partial derivatives with account of gyroscopic inertia forces. Low rigidity, large

(C) Lizunov P.P., Nedin V.O. 
length, relatively high values of the excitation intensity parameters, in which the structural elements are used, all of these make the necessary to analysis of oscillatory motion around of critical and overcritical rotational speeds. Also, these make the necessary to search the natural oscillation frequencies range and range of critical rotational speeds with account of gyroscopic forces, and stability analysis in the study of different motion modes.

In recent years, the dynamic tasks of oscillations of shafts and rotating rods were investigated in works of many authors. The task of rotating shaft with influence of axial loads to the propagation characteristics of the elastic waves is studied in paper [14]. The shaft is viewed with non-uniform cross-sections per length. Axial loads considered with constant values.

The paper [8] presents the study of problems with elastic stabilization and long-term strength of the system under cyclically changing external impacts that are appearing because of eccentricities. Task is considered taking into account the gyroscopic loads, in linear statement. The paper [7] presents the results of study of space bending oscillations of horizontal rod that is rotating around its axis. Rod is under the action of periodic harmonic force of self-weight per length. The task is considered with account of the gyroscopic loads, too.

Questions about the transverse oscillations of the rods under the action of axial periodic loads, also the tasks of longitudinal-transverse oscillations under the action of beat loads are considered in papers $[5,6]$. But in them the investigated rods don't rotate.

The analysis of presented in scientific literature results shows that the task of investigation of dynamics and strength of rotating elastic systems, with account of gyroscopic forces, is actual. Many authors are paid attention to calculation of critical rotational speeds and natural oscillation frequencies by different system parameters. But the nature of the oscillation process itself and how the certain parameters of the system influence on the development of oscillations almost is not considered. Therefore, it is interesting to study the dynamic behavior of the consider systems and define what kind of effects the gyroscopic forces generate.

Problem statement. In the process of oscillation of rotating shafts or rods with considerable lengths with different physical, geometric and dynamic parameters, the various bend forms that change in time are possible.

As a dynamic model is considered a rod with length $l$ (Fig. 1) that can be exposed by action of an axial load $P(t)$. The rod is rotated on angular speed $\omega$

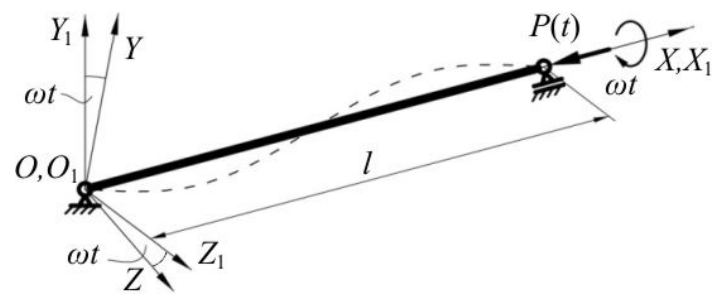

Fig. 1. Dynamic model of system around the rectilinear axis $O_{1} X_{1}$ of the stationary coordinate system $O_{1} X_{1} Y_{1} Z_{1}$. The rotating coordinate system $O X Y Z$ is tied to the rod and rotates with it. The direction of $O X$ axis coincides with 
direction of $O_{1} X_{1}$ axis. Axis of rod in deformed state is coincided with the $O X$ and $O_{1} X_{1}$ axis. The oscillatory motion of the rod in the $O X Y Z$ coordinate system is characterized by $y(x, t)$ and $z(x, t)$ displacements of the points, that belong to the axis of rod in the $O Y$ and $O Z$ coordinate axes' direction, respectively.

The oscillations of rotating rod in space are described by the corresponding system of differential equations, which taking into account the geometric nonlinearity and the axial force $[2,3]$ have a form:

$$
\left\{\begin{array}{l}
\frac{d^{2}}{d x^{2}}\left(\frac{E I_{1(x)}}{\rho_{1}}\right)-\bar{m} r^{2}\left(\frac{d^{4} y}{d t^{2} d x^{2}}+\omega^{2} \frac{d^{2} y}{d x^{2}}\right)-2 \omega \bar{m} \frac{d z}{d t}-\bar{m} \omega^{2} y+\bar{m} \frac{d^{2} y}{d t^{2}}+P(t) \frac{d^{2} y}{d x^{2}}=0, \\
\frac{d^{2}}{d x^{2}}\left(\frac{E I_{2(x)}}{\rho_{2}}\right)-\bar{m} r^{2}\left(\frac{d^{4} z}{d t^{2} d x^{2}}+\omega^{2} \frac{d^{2} z}{d x^{2}}\right)+2 \omega \bar{m} \frac{d y}{d t}-\bar{m} \omega^{2} z+\bar{m} \frac{d^{2} z}{d t^{2}}+P(t) \frac{d^{2} z}{d x^{2}}=0,
\end{array}\right.
$$

where $E$ - elastic modulus of rod's material; $I_{1}, I_{2}$ - inertia moments of rod section in mutually perpendicular planes; $r$ - radius of gyration; $\bar{m}$-mass of unit per length; $\omega$-rotational speed of rod around the axis that coincides with the axis of rod in undeformed state; $P(t)$ - periodic axial force; $1 / \rho_{1}, 1 / \rho_{2}-$ main curvatures of rod's axis in mutually perpendicular planes.

Technique. The solving of differential equations of rotating rods oscillations for searching their geometric position in space in the process of oscillation and analysis of dynamic behavior is carried out using the method of numerical differentiation described in papers $[10,11]$, and the Houbolt time integration method [13] in form:

$$
\begin{aligned}
& \ddot{y}_{n}^{t+\Delta t}=\frac{1}{\Delta t^{2}}\left[2 y_{n}^{t+\Delta t}-5 y_{n}^{t}+4 y_{n}^{t-\Delta t}-y_{n}^{t-2 \Delta t}\right], \\
& \dot{y}_{n}^{t+\Delta t}=\frac{1}{6 \Delta t}\left[11 y_{n}^{t+\Delta t}-18 y_{n}^{t}+9 y_{n}^{t-\Delta t}-2 y_{n}^{t-2 \Delta t}\right], \\
& \ddot{z}_{n}^{t+\Delta t}=\frac{1}{\Delta t^{2}}\left[2 z_{n}^{t+\Delta t}-5 z_{n}^{t}+4 z_{n}^{t-\Delta t}-z_{n}^{t-2 \Delta t}\right] \\
& \dot{z}_{n}^{t+\Delta t}=\frac{1}{6 \Delta t}\left[11 z_{n}^{t+\Delta t}-18 z_{n}^{t}+9 z_{n}^{t-\Delta t}-2 z_{n}^{t-2 \Delta t}\right]
\end{aligned}
$$

Such solution executes in order to find the coordinates $y_{n}^{t+\Delta t}, \quad z_{n}^{t+\Delta t}$ of $\operatorname{rod}$ axis for next point of time $t+\Delta t$ (Fig. 2).

To apply the Houbolt method need to know at least the first three points of time integration. To find these points, it is

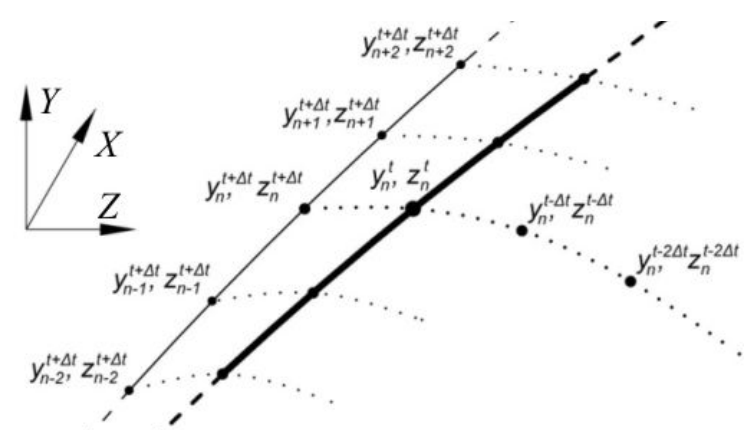

Fig. 2. Rod's motion trajectory 
advisable to use the finite differences method with initial conditions, namely, to make the assumption that at time $t=0$, when the system start out of equilibrium, the initial deviation value for each point of the rod axis is known: $y_{n}^{t=0}=a_{n}, z_{n}^{t=0}=0$, where $a_{n}$ is random deviation, and values $y_{n}^{\Delta t}=y_{n}^{-\Delta t}$, $z_{n}^{\Delta t}=z_{n}^{-\Delta t}$.

The solving of the dynamic tasks of the oscillatory motion for rotating shafts and rods, based on described technique, has been done with computer program with a graphical interface. The general block diagram's algorithm of the program is shown in Figure 3.

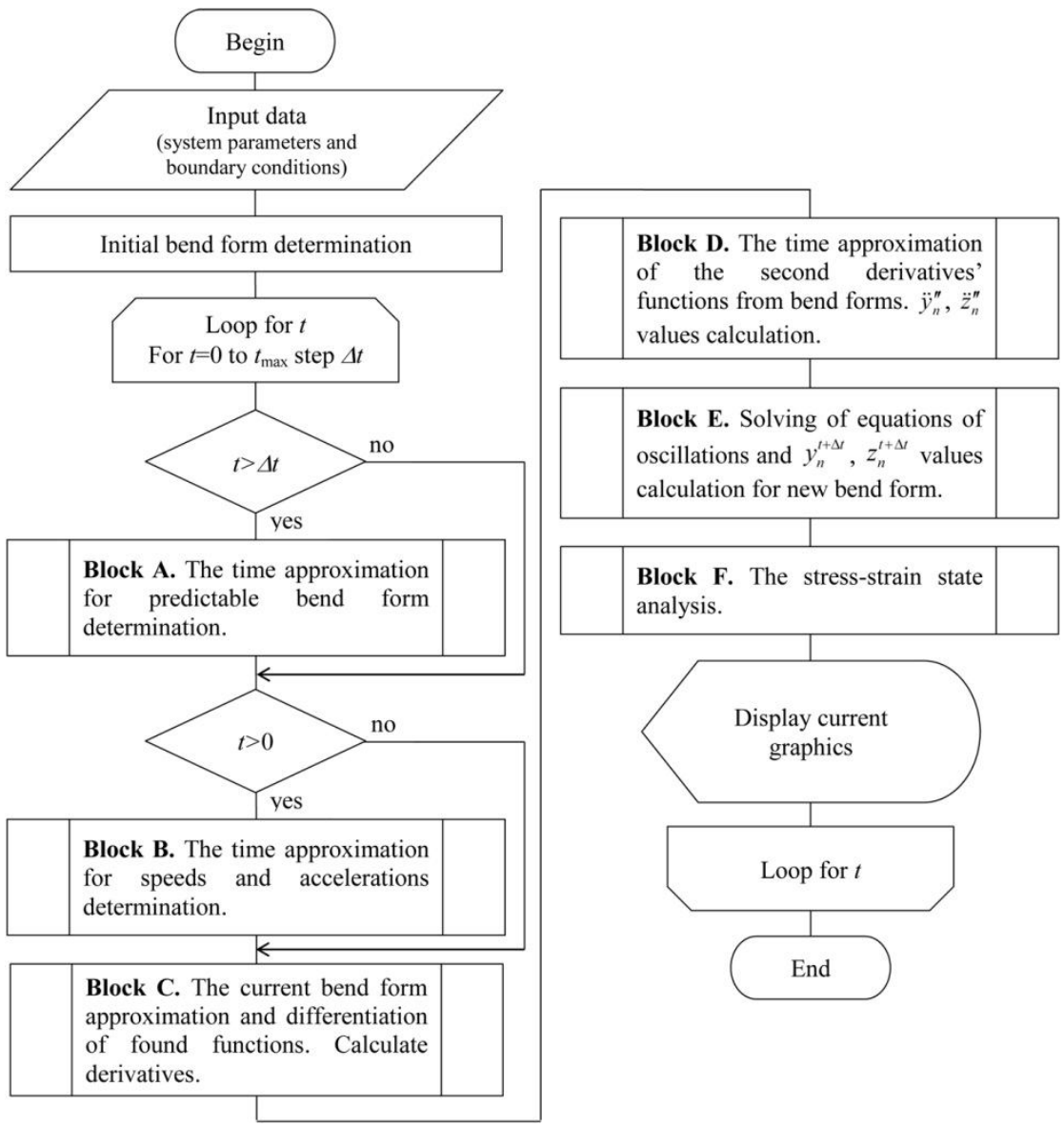

Fig. 3. The general block diagram algorithm of the program

This algorithm describes the process of repeated (cyclical) solving the system of differential equations of oscillations for every point of rod elastic line in order to find the new coordinates for these points in each next point of time $t+\Delta t$. This 
is performed with the show of current calculations' results as a moving computer model, which displays the oscillating process of rotating rod in real time.

Results. Using specified program, the dynamics of a range of objects which are modeled by long elastic rods have been studied. For research objects is shown that on special rotational speeds of shafts with different lengths the trajectories of center of the section have an ordered character. For example, for a transmission shaft with outer diameter $D=0.1 \mathrm{~m}$, inner diameter $d=0.06 \mathrm{~m}$, length $l=3 \mathrm{~m}$, on rotational speed $\omega=31.79 \mathrm{~s}^{-1}$ the motion trajectory of center of the section on the middle of shaft, in rotating coordinate system, it will look like a five-pointed star (Fig. 4). On rotational speed $\omega=52.95 \mathrm{~s}^{-1}$ in rotating coordinate system the motion trajectory will look like a tree-pointed star (Fig. 5). On rotational speed $\omega=79.35 \mathrm{~s}^{-1}$ in rotating coordinate system the motion trajectory will look like a four-pointed star (Fig. 6). Herewith, the trajectories of motion in a stationary coordinate system will have a similar character (Fig. 7, 8, 9). The same trajectories of motion are observed for other objects with different parameters, but on other rotational speeds.

The shown below on diagrams trajectories due to the action of gyroscopic inertia forces that are arisen in rotation.

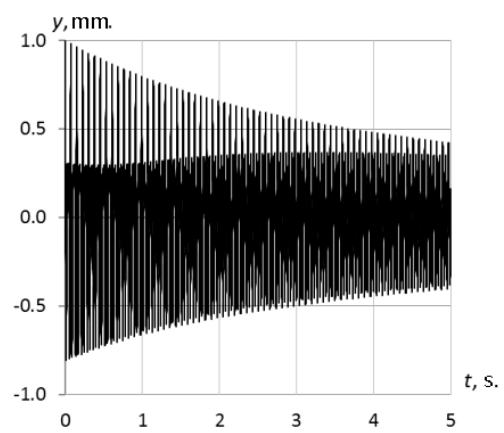

(a)

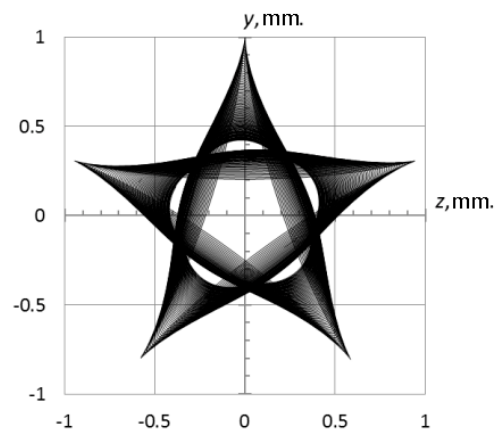

(b)

Fig. 4. Shaft oscillation diagrams in rotating coordinate system, on speed $\omega=31.79 \mathrm{~s}^{-1}$ :

(a) oscillation; (b) the motion trajectory

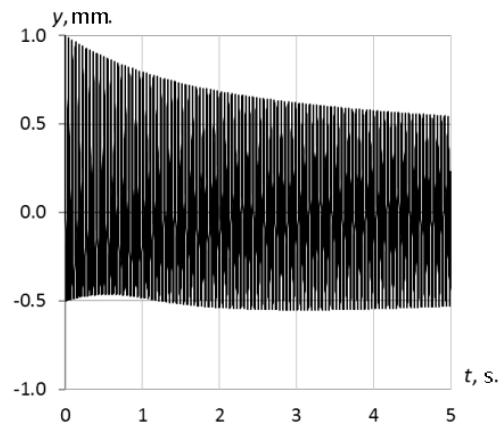

(a)

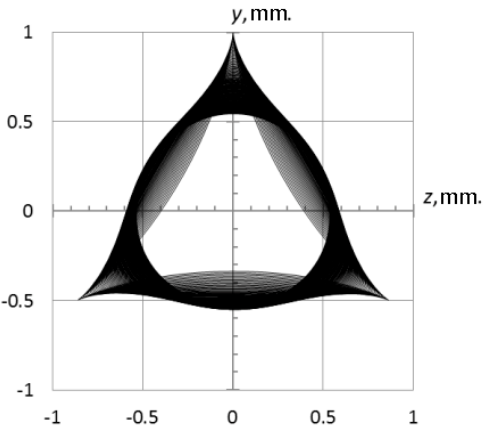

(b)

Fig. 5. Shaft oscillation diagrams in rotating coordinate system, on speed $\omega=52.95 \mathrm{~s}^{-1}$ :

(a) oscillation; (b) the motion trajectory 


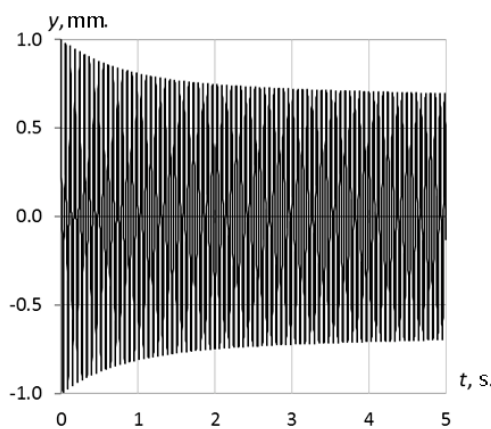

(a)

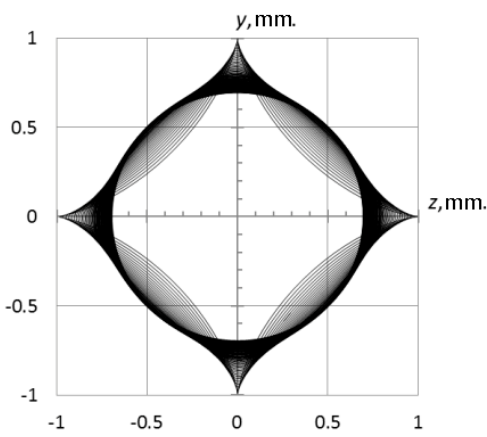

(б)

Fig. 6. Shaft oscillation diagrams in rotating coordinate system, on speed $\omega=79.35 \mathrm{~s}^{-1}$ : (a) oscillation; (b) the motion trajectory

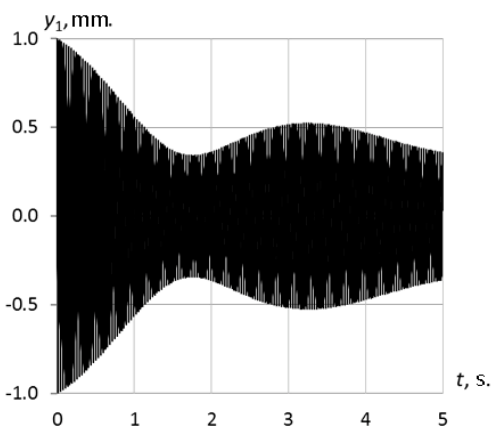

(a)

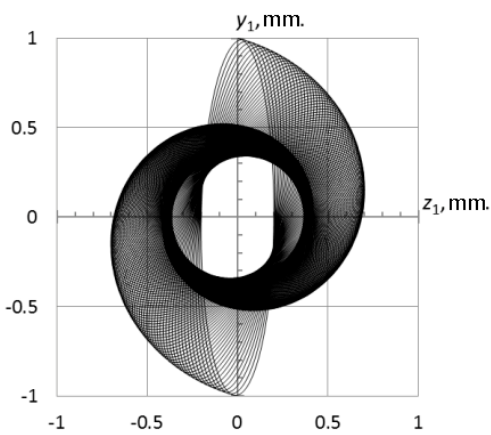

(b)

Fig. 7. Shaft oscillation diagrams in stationary coordinate system, on speed $\omega=31.79 \mathrm{~s}^{-1}$ : (a) oscillation; (b) the motion trajectory

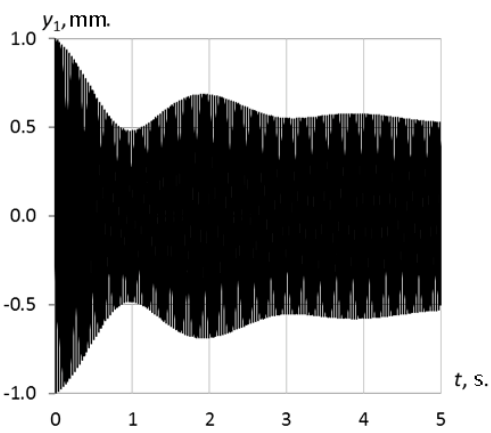

(a)

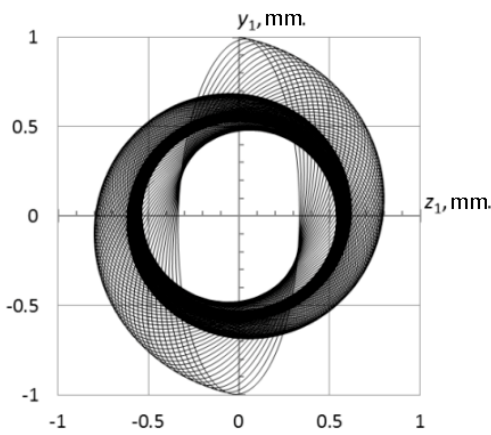

(b)

Fig. 8. Shaft oscillation diagrams in stationary coordinate system, on speed $\omega=52.95 \mathrm{~s}^{-1}$ : (a) oscillation; (b) the motion trajectory 


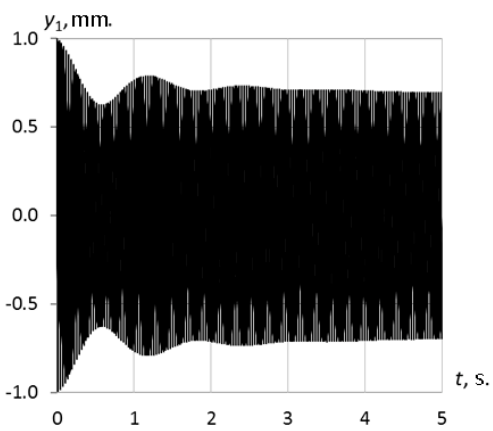

(a)

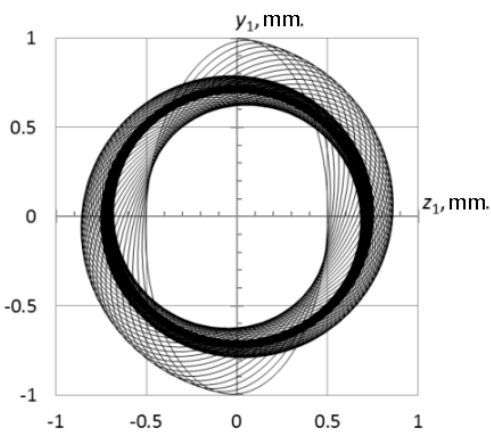

(b)

Fig. 9. Shaft oscillation diagrams in stationary coordinate system, on speed $\omega=79.35 \mathrm{~s}^{-1}$ : (a) oscillation; (b) the motion trajectory

Conclusion. Studies of the transverse oscillations of rotating shafts with developed computer program indicate the influence of gyroscopic forces on the nature of oscillatory motion. Depending on the rotational speed the oscillatory motion of the shaft occurs with different trajectories, which at certain speeds have a definite periodicity.

The rotational speeds at which the motion trajectories during transverse shaft oscillations have an ordered character in the form of an $n$-pointed star are found. Such motion happens in the time interval from the moment of excitation to the start of the established circulation with amplitude that harmoniously changes in time.

\section{REFERENCES}

1. Bakhvalov N.S., Judkov N.P., Kobelkov G.M. Chislennye metody (Numerical methods). M.: BINOM, Laboratoriya znaniy, 2015, 639 pp.

2. Bolotin V.V. Dinamicheskaya ustoychivost uprugih system (The dynamic stability of elastic systems). M.: Izdatelstvo tekhniko-teoreticheskoj literatury, 1956, $600 \mathrm{pp}$.

3. Dimentberg F.M. Izgibnyye kolebaniya vrashchayushchikhsya valov (Flexural vibrations of rotating shafts). Moscow: Publishing of AS USSR, 1959, 247.

4. Karpenko T. N., Muzyka I. N. Determination of natural frequencies of bending vibrations of rotating shafts. Science and production, 2018, No. 18, 69-78.

5. Morozov N.F. Static and Dynamics of a Rod at the Longitudinal Loading / N.F. Morozov, P.E. Tovstik, T.P. Tovstik // Vestnik YUUrGU. Seriya «Matematicheskoye modelirovaniye i programmirovaniye». - 2014. - Vol. 7, No. 1. - S. 76-89.

6. Morozov N.F. The rod dynamics under short longitudinal impact / N.F. Morozov, P.E. Tovstik // Vestnik SPbGU. - 2013. - Vup. 3. P.131-141.

7. Munitsyn A.I. Prostranstvennyye izgibnyye kolebaniya sterzhnya, vrashchayushchegosya vokrug svoyey osi (Space bending oscillations of a rod rotating around its axis) // Matematicheskoye i komp'yuternoye modelirovaniye mashin i sistem. -2008. S. 64-67.

8. Murtazin I.R. Research of flexural vibrations of rotating shafts with distributed inertial, elastic and eccentricity properties / I.R. Murtazin, A.V. Lukin, I.A. Popov // Scientific and Technical Journal of Information Technologies, Mechanics and Optics. - 2019. - Vol. 19, no. 4, P. 756766.

9. Nedin V.O. Computer modeling of the oscillation's process of rotating elastic rods // Modern methods and problem-oriented complexes for structures calculating and their application in design and educational process. - 2018. - No. 2, 76- 78 . 
10. Nedin V.O. 2020. The parametric oscillations of rotating rods under action of the axial beat load // Strength of materials and theory of structures. - 2020. - Issue 104, P. $309-320$.

11. Nedin $V$. Numerical differentiation of complex bend forms of long rotating rods // Management of Development of Complex Systems. - 2020. - No. 43, P. 110-115.

12. Tondl A. Dinamika rotorov turbogeneratorov (The rotor dynamics of turbines). L., Energiya, 1971, $297 \mathrm{pp}$.

13. Maurice Petyt. Introduction to Finite Element Vibration Analysis. Cambridge University Press, 1990. $-558 \mathrm{p}$.

14. Yimin Wei. Influence of Axial Loads to Propagation Characteristics of the Elastic Wave in a Non- Uniform Shaft / Yimin Wei, Zhiwei Zhao, Wenhua Chen and Qi Liu // Chinese Journal of Mechanical Engineering. - 2019 - No. 32:70. P.13.

Стаття надійшла 12.04.2020

\section{Лізунов П.П., Недін В.О. \\ ВПЛИВ ГІРОСКОПІЧНИХ СИЛ НА КОЛИВАЛЬНИЙ РУХ ВАЛІВ ПРИ ОБЕРТАННI}

Представлено результати чисельного дослідження поперечних коливань валів 3 урахуванням гіроскопічних сил інерції. Показано, який вплив гіроскопічні сили оказують на поперечні коливання валів при обертанні. Дослідження здійснені за допомогою комп'ютерної програми з графічним інтерфейсом, що розроблена автором. Описано процес чисельного розв'язання рівнянь коливального руху з використанням методики чисельного диференціювання, в якій форми вигину стержнів описуються за допомогою поліноміальних сплайн-функцій, а також метода чисельного інтегрування за часом Хубболта. Наведена загальна блок-схема алгоритму, який описує процес багатократного (циклічного) розв'язку системи рівнянь коливального руху для кожної точки системи 3 метою пошуку нових координат положення цих точок в кожний наступний момент часу $t+\Delta t$. Комп'ютерна програма, в якій реалізовано наведений алгоритм, дозволяє спостерігати за поведінкою рухомої комп'ютерної моделі, яка демонструє процес коливального руху при обертанні, а також будувати графіки коливального руху, графіки зміни швидкостей та прискорень в різних системах координат, визначати області динамічної стійкості об'єктів, що розглядаються. Використовуючи зазначену програму, здійснено дослідження динаміки ряду об'єктів, робочі органи яких моделюються довгомірними пружними стержнями. Для об'єктів дослідження показано, що при певних швидкостях обертання валів та стержнів різної довжини в системі координат, що обертається разом 3 валом або стержнем, траєкторія руху центра перерізу вала має упорядкований характер у вигляді $n$-кінцевої зірки на інтервалі часу від моменту збудження до початку встановленого кругового коливального руху з амплітудою, що гармонійно змінюється за часом. Відмічено, що такі траєкторії руху обумовлені дією гіроскопічних сил інерції, які виникають при обертанні.

Ключові слова: вали, поперечні коливання, чисельне диференціювання, форми вигину, гіроскопічні сили.

\section{Лизунов П.П., Недин В.О.}

\section{ВЛИЯНИЕ ГИРОСКОПИЧЕСКИХ СИЛ НА КОЛЕБАТЕЛЬНОЕ ДВИЖЕНИЕ ВРАЩАЮЩИХСЯ ВАЛОВ}

Представлены результаты численного исследования поперечных колебаний валов с учётом гироскопических сил. Показано, какое влияние гироскопические силы оказывают на поперечные колебания вращающихся валов. Исследования осуществлены с помощью компьютерной программы с графическим интерфейсом, которая была разработана автором. Описан процесс численного решения уравнений колебательного движения с использованием методики численного дифференцирования, в которой формы изгиба стержней описываются с помощью полиномиальных сплайн-функций, а также метода численного интегрирования по времени Хубболта. Показана общая блок-схема алгоритма программы, который описывает процесс многократного (цикличного) решения системы уравнений колебательного движения для каждой точки системы с целью поиска новых координат положения этих точек в каждый следующий момент времени $t+\Delta t$. Компьютерная программа, в которой реализован представленный алгоритм, позволяет наблюдать за поведением компьютерной модели, демонстрирующей процесс 
колебательного движения при вращении, а также строить графики колебательного движения, графики изменения скоростей и ускорений в разных системах координат, определять области динамической неустойчивости рассматриваемых объектов. Используя указанную программу, выполнено исследование динамики рядя объектов, рабочие органы которых моделируются длинными упругими стержнями. Для объектов исследования показано, что при определённых скоростях вращения, в системе координат, вращающейся вместе с валом, траектория движения его центра сечения имеет упорядоченный характер в виде $n$-конечной звезды на интервале времени от момента возбуждения до начала установившегося кругового колебательного движения с гармонически изменяющейся во времени амплитудой. Отмечено, что такие траектории движения обусловлены действием гироскопических сил, которые возникают при вращении.

Ключевые слова: валы, поперечные колебания, численное дифференцирование, формы изгиба, гироскопические силы.

\section{УДК 539.3}

Лізунов П.П., Недін В.О. Вплив гіроскопічних сил на коливальний рух валів при обертанні // Опір матеріалів і теорія споруд: наук.-тех. збірн. - К.: КНУБА, 2020. - Вип. 105. - C. $223-231$.

В роботі наведені результати чисельного дослідження поперечних коливань валів 3 урахуванням гіроскопічних сил інериіі. Показано, який вплив гіроскопічні сили оказують на поперечні коливання валів при обертанні.

Табл. 0. Іл. 9. Бібліогр. 14 назв.

\section{UDC 539.3}

Lizunov P.P., Nedin V.O. The gyroscopic forces influence on the oscillations of the rotating shafts // Strength of Materials and Theory of Structures: Scientific-and-technical collected articles - Kyiv: KNUBA, 2020. - Issue 105. - P. 223 - 231.

The paper presents the results of numerical investigation of shafts transverse oscillations with account of gyroscopic inertia forces. It is shown what the action and how the gyroscopic forces influence on the transverse oscillations of the shafts during rotation.

Tabl. 0. Fig. 9. Ref. 14.

\section{УДК 539.3}

Лизунов П.П., Недин В.О. Влияние гироскопических сил на колебательное движение вращающихся валов // Сопротивление материалов и теория сооружений: науч.- тех. сборн. - К.: КНУСА, 2020. - Вып. 105. - С. 223 - 231.

В работе представлены результаты численного исследования поперечных колебаний валов с учётом гироскопических сил инериии. Показано, какое влияние гироскопические силь оказывают на поперечные колебания вращающихся валов.

Табл. 0. Ил. 9. Библиогр. 14 назв.

Автор (науковий ступень, вчене звання, посада): доктор технічних наук, професор, завідувач кафедри основ інформатики КНУБА, ЛІЗУНОВ Петро Петрович.

Адреса робоча: 03037 Украӥна, м. Київ, Повітрофлотський проспект 31, КНУБА, кафедра основ інформатики, ЛІЗУНОВ Петро Петрович.

Адреса домашня: Украӥна, м. Київ, вул. Кавказька, 12, кв. 48.

Мобільний тел.: +38(067) 921-70-05

E-mail: lizunov@knuba.edu.ua

ORCID ID: http://orcid.org/0000-0003-2924-3025

Автор (науковий ступень, вчене звання, посада): асистент кафедри основ інформатики НЕДІН Валентин Олегович.

Адреса робоча: 03037 Украӥна, м. Київ, Повітрофлотський проспект 31, КНУБА, кафедра основ інформатики, НЕДІН Валентин Олегович.

Адреса домашня: 04213 Україна, м. Київ, вул. Північна 50, кв. 181.

Мобільний тел.: +38(067) 764-95-52

E-mail: nedin.vo@knuba.edu.ua

ORCID ID: http://orcid.org/0000-0003-3138-2892 